Research.

\title{
The effect of quality of the service upon customer satisfaction at royal safari garden resort and convention Cisarua Bogor
}

\author{
Dwi Gemina \\ Fakultas Ekonomi Universitas Djuanda Bogor \\ dwigemina@gmail.com \\ Rully Zulkiply \\ Fakultas Ekonomi Universitas Djuanda Bogor
}

Received: July 25, 2019; Accepted: August 12, 2019; Published: December 31, 2019

To cite this article: Gemina, Dwi, Rully Zulkiply. 2019. The Effect of Quality of The Service Upon Customer Satisfaction at Royal Safari Garden Resort and Convention Cisarua Bogor. The Management Journal of BINANIAGA. 4 (2): 21-32. doi: 10.33062/mjb.v4i2.333

\begin{abstract}
This research aims to analyze the impact of quality of the service upon customer satisfaction at Royal Safari Garden Resort and Convention Cisarua Bogor. The questionniares have been distributed to 100 respondents. Type of the research is descriptive and verificative one. The questionnaire has applied validity test, reliability test and classics assumption. Likert scale has been used before applying multiple regression test to see the effect of five independent variables upon one dependent variable. The result has indicated that simultaneously and partially quality service (physical evidence, emphaty, reliability, responsiveness and guarantee) has positively and significantly affected the Customers satisfaction at Royal Safari Garden Resort and Convention Cisarua Bogor.
\end{abstract}

Keywords : Service Quality, Customer Satisfaction, Royal Safari Garden Resord and Convention Cisarua Bogor.

Nowadays, globalization era has made tourism requirement as primary needs dominating people life. As a matter of fact, holiday is required by the people who want to escape from their routine job, and for tourism business producers, it is a profitable business opportunity. Tourism sector has provide a big role supporting the development of a country which is a source of foreign exchange and local income that can increase the development of people economy. (Soebagyo, 2012:6). Hotels, restaurant and trading have been becoming important.

Based on the data of National Statistics Center/ BPSN (2018) mentioned that Indonesia Economy in 2017 and refered to Gross Domestic Product (PDB/GDP) had gained Rp. 13.589 trillion and the highest one was Rp. 2.749 .3 billion or $21 \%$ which was coming from manufacturing industires. However, accommodation services sectors had achieved Rp 387.5 billion or $2.97 \%$ of total GPD in 2017 . It has explained that service facility category has had an economic potential development in Indonesia. Total of the hotels at all provinces in Indonesia has been developing on average $10.13 \%$ within 5 years. In 2016 Bali province, West Java and DKI Jakarta had been the three biggiest provinces having 317 hotels, 314 hotela and 232 hotels.

As a business unit dealing with hospitality, service excellent is the priority intention of a company. An excellent service given by a company will create the customer satisfaction. Customer satisfaction is an expectation required by a customer about service of excellent provided by a hotel (Park quoted in Normasari, 2013:3). Service quality is a success key of hospitality business where some dimensions are required such 
as physic evidence, reliability, responsiveness, assurance and empathy. Royal Safari Garden Resort and Convention Cisarua Bogor is one of the four stars hotels in Bogor district which is keeping the commitment to provide the best service. This commitment has brought the hotel got some prestige awards of hotel recommended by TipAdvisor which is the biggest tourism webs announcing Royal Safari Garden Resord and Convention Cisarua Bogor is appraised to receive the first one out of 25 hotels in Puncak.

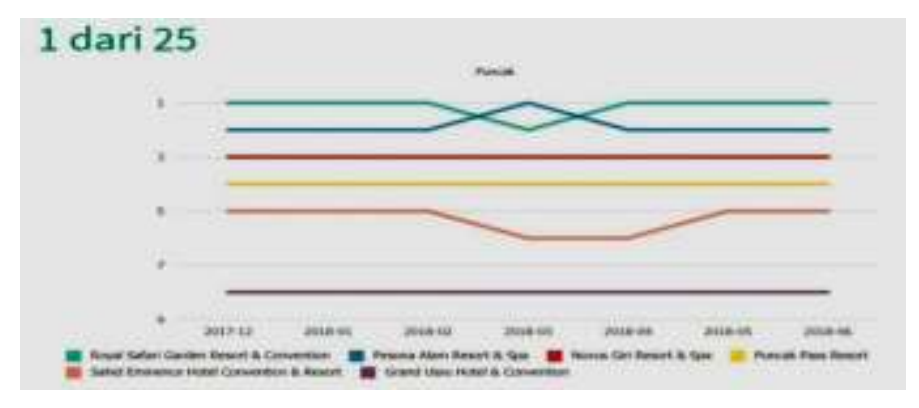

Graph. Level of Hotel recommended in TripAdvisor 2017.

Source : TripAdvisor.com, 2018 accessed on 30.06.2018:19.00 (West Indonesia Time)

However, unfortunately this award has not given a good result achieving the target of hotel visitors staying in the hotel. In 2014 to 2016, occupation of the rooms had achieved the target of $87.83 \%$. But, in 2017 it was the lowest target achievement of $75.04 \%$.. This reducing of the total of people visited the hotel in 2017 was due to many hotels and competitors appeared in Cisarua Bogor District and due to area construction developed in front of the hotel. Nevertheless, it happened because of the gap of customers expectation with quality of service. This circumstance needs a serious attention, because it is the reflection of customers dissatisfaction. Since there have been so many complaints received, the hotel has to improve the quality of service given to the customers to make them satisfied.

\section{Library Review}

\section{Quality of the Service}

Facing a lot of competitors, hotels should have to do some strategies to make the customers to be loyal with. Lupiyoadi (2014:216)said that quality of the service is to the extent of which the customers expectation against the service received. Service quality is a main gap expected and a control to meet the customer need (Tjiptono, 2014:59). A method is to be available to measure the quality of a service. In the study of Service Quality done by Parasuraman, et al. quoted in Lupiyoadi (2014:216-217), five dimensions are avaialbe such as physical evidence, empathy, reliability, responsiveness, and assurance. Service quality refers to : 1) physical evidence (tangible) is an organization power to show its existence to external parties. Appearance is also a physical facility and infrastructure which can be trusted refers to the environmental condition which is a real evidence about the service given to the customers ; 2) Empathy is an honest attention given individually to the customer and the effort to understand the customer requirement. An organization is required to have an understanding and knowledge about customers, know exactly the customers specific needs and a comfortable time of the service for the customers ; 3) Reliability is an organization power to provide a good and trusted service as promised. The same good performance is expected by the customers which is time, same good service provided for each customers, high quality of behavior and truth; 4) Responsivenss is quick help and service and accurate information given to the customers; 5) Assurance is about behavior and employees succeeded to make the customers trust the organization. 


\section{Customers Satisfaction}

Referring to Kotlers quoted in Lupiyoadi (2014:192), customer satisfaction is the extent to which of someone declares comparison of the result between product or service performance received with his/her expectation. But according to Tjiptono (2013:311) described that customer satisfaction is a customer feed-back about the product or service expected before and after the product or service consumed. Customers satisfaction can be defined after they consume the product or service, or in other words, customer satisfaction is the evaluation of the product purchased whether it has satisfied the customer (Yamit, 2013:78)

\section{Hypotheses Development}

Service quality according to Lupiyoadi (2014:216) is to what extent of the difference of product/service expected and received. If the service quality received is the same with the expectation of the customers, they will satisfy and will reuse it. Based on the research of Suryadharma and Nurcahya (2015), described that quality of service will give posititive effect upon the customers of a hotel.

In a service company, especially hotels, as a matter of fact, physical condition factor will give a description of the related hotel whether or not the customer is deserved to stay overnight. The better the feed-back from customer about physical evidence(tangible) is, the higher the satisfaction of customer will be. According to Lupiyoadi (2014:216) said that service quality of marketing a service is depending on the physical evidence which is the condition of facilities and infrastructure of the organization or surrounding environments which are expected comfortable. Besides of physical evidence, empathy is also an important factor in providing service of excellent to the customer. In compliance with Lupiyoadi (2014:216), empathy is an honest attention given to the customers personally to understand their needs.

Reliability is the power of an organization to give a service as promised. According to Hamzenah (2003:25) in order to win the competitor in marketing the service, it has to focus on reliable service offered which is in accordance with the standard of service reliability.

Hotel is a public place for a person to stay over night and take a rest. So that, hotel has to be able to handle all complaints from the customers. As described by Lupiyoadi and Hamdani (2006:182), responsiveness will help or provide quick service and accurate information, but if the customers have to wait, it is negative feed-back of service quality.

Assurance is consisting of knowledge, trustworthy behavior of the stafsf and the place is free from danger, risk or suspiciousness..According to Lupiyoadi (2014:216), it is a science, behavior and power of the employees of an organization to develop customers trust. Referring to the experts and researches above, hypotheses of this research are as follows: 1) Service Quality has positively and significantly affected customer satisfaction; 2) Physical Evidence(Tangible) has positively and significantly affected customer satisfaction. ; 3) Empathy has positively and significantly affected customer satisfaction; 4) Realibility has positively and significantly affected customer satisfaction; 5) Responsiveness has positively and significantly affected customer satisfaction; 6) Assurance has positively and significantly affected customer satisfaction. 


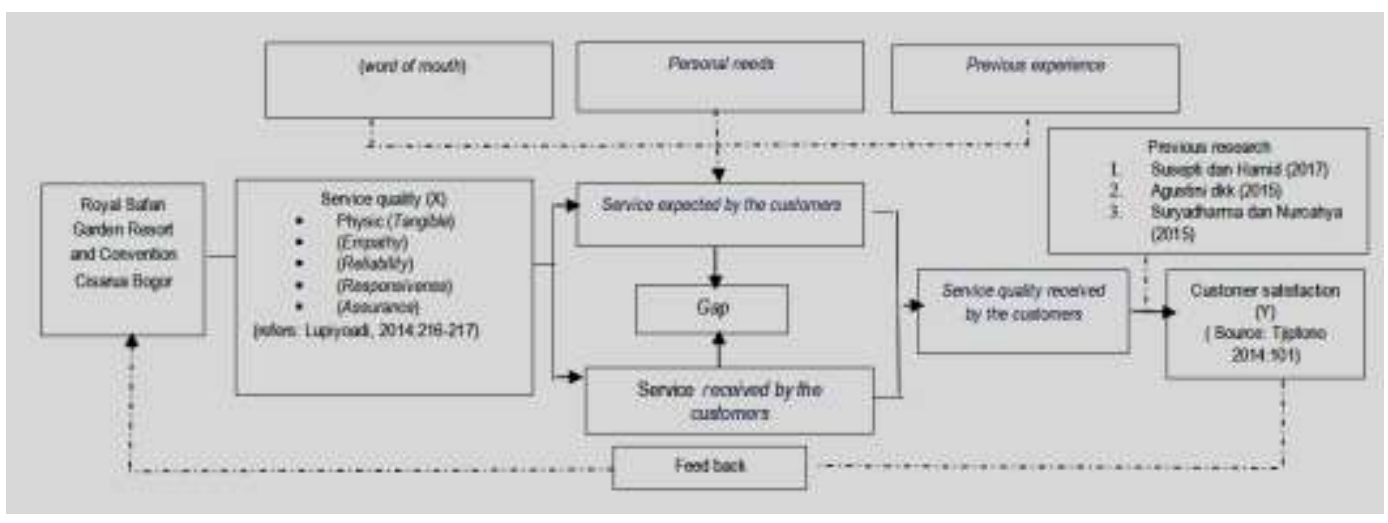

Drawing. Research Design

\section{Research Method}

\section{Object, Location and Sample of the Research}

Object of the research is the guests or customers of Hotel Royal Safari Garden Resort and Convention Cisarua Bogor locates at Jalan Raya Puncak-Cisarua No.601. Cisarua - Bogor District 16750. West Java. Royal Safari Garden Resort andConvention is a four stars hotel which is a resort having natural tourism location and entertainments with varied facilities for the family. Research analysis unit is hotel customers. To define the respondents as representative sample, sampling technics has applied slovin equation which is 100 customers. To measure the sample of respondent size at each room has applied proportionate stratified random sampling which is sampling technics of the population having non homogeneous member or element and proportional structure.

Table. Total of sample of the customers at Leopard Building

\begin{tabular}{|c|c|c|c|c|}
\hline No & $\begin{array}{c}\text { Type of room and } \\
\text { bungalow }\end{array}$ & Total Customers & Calculation & Total Samples \\
\hline 1 & Leopard Grand Deluxe & 2752 & $(2752 / 13.320) \times 100$ & 21 \\
\hline 2 & Leopard Executive & 10050 & $(10050 / 13.320) \times 100$ & 75 \\
\hline 3 & Leopard Suite & 518 & $(518 / 13.320) \times 100$ & 4 \\
\hline & Total & 13.320 & & 100 \\
\hline
\end{tabular}

Source : Data processed , 2018

\section{Research Design, Operational Variable and Method of Data Analysis}

Type of this research has used descriptive research which is a formula related to the question about individual factor, either one or more than one factors and a vericative research which is a research testing the hypotheses obtained from descriptive research by using statistics calculation to prove either the hypothesis is accepted or rejected (Sugiyono, 2012:6). Data examination has used validity test, reliability test, classics assumption test which is normality test, multicolonierity test, and heteroscedasticy test. After all the instruments have been tested, multiple linear regression, multiple correlation, determinant coefficient, simultant hypotheses test ( $T$-test) and finally partial test will be done.. Operational variable described is to identify some constructs as well as marks to be studied to enable measuring the variables. Operational variable of this research is service quality and customer satisfaction, as the following: 
Table. Operational Variable

\begin{tabular}{|c|c|c|c|}
\hline Variable & Sub Variable & Concept of Sub Variabel & Indicator \\
\hline \multirow{20}{*}{$\begin{array}{l}\text { Service } \\
\text { Quality (X) }\end{array}$} & \multirow{4}{*}{$\begin{array}{l}\text { Physical } \\
\text { Evidence } \\
\text { (Tangible) }\left(X_{1}\right)\end{array}$} & \multirow{4}{*}{$\begin{array}{l}\text { Organization capability to show } \\
\text { its existence to external } \\
\text { party(Lupiyoadi, 2014:216-217) }\end{array}$} & 1. Attractive building \\
\hline & & & 2. Comfortable place \\
\hline & & & 3. Complete facilities offered \\
\hline & & & 4. Neatness of the employees \\
\hline & \multirow[t]{4}{*}{ (Empathy) $\left(\mathrm{X}_{2}\right)$} & \multirow{4}{*}{$\begin{array}{l}\text { Providing honest attention and } \\
\text { personal or individual support to } \\
\text { understand consumer } \\
\text { needs(Lupiyoadi, 2014:216-217) }\end{array}$} & 1. 24 hours service \\
\hline & & & $\begin{array}{l}\text { 2. Know the customers } \\
\text { requirement. }\end{array}$ \\
\hline & & & 3. Good communication skils \\
\hline & & & 4. Personally and individually care \\
\hline & \multirow[t]{4}{*}{ (Reliability) $\left(X_{3}\right)$} & \multirow{4}{*}{$\begin{array}{l}\text { Organization power to provide } \\
\text { the same service as promised } \\
\text { which is trustworthy and true } \\
\text { (Lupiyoadi, 2014: 216-217 }\end{array}$} & 1. Quck service \\
\hline & & & Servicing procedure \\
\hline & & & 3. Service Excellent \\
\hline & & & 4. Punctuality \\
\hline & \multirow{4}{*}{$\begin{array}{l}\text { (Responsivenes } \\
\text { s) }\left(X_{4}\right)\end{array}$} & \multirow{4}{*}{$\begin{array}{l}\text { The way how to help and to } \\
\text { provide quick, accurate and } \\
\text { clear information (Lupiyoadi, } \\
\text { 2014:216-217) }\end{array}$} & 1. Response the customer complaint \\
\hline & & & $\begin{array}{l}\text { 2. Employee is ready to help the } \\
\text { customer. }\end{array}$ \\
\hline & & & 3. Quick problem solving \\
\hline & & & 4. Clear to provide an information \\
\hline & \multirow{4}{*}{$\begin{array}{l}\text { (Assurance) } \\
\left(X_{5}\right)\end{array}$} & \multirow{4}{*}{$\begin{array}{l}\text { Knowledge, politeness and skills } \\
\text { of the employees to develop } \\
\text { customer trust (Lupiyoadi, } \\
\text { 2014:216-217) }\end{array}$} & 1. Politeness of customer service. \\
\hline & & & 2. Extensive knowledge \\
\hline & & & 3. Customer safety \\
\hline & & & 4. Ensure the customer trust \\
\hline \multirow{5}{*}{\multicolumn{2}{|c|}{ Customer Satisfaction $(\mathrm{Y})$}} & \multirow{5}{*}{$\begin{array}{l}\text { Customers feed-back about the } \\
\text { product or service expected and } \\
\text { received (Tjiptono, 2014:311) }\end{array}$} & $\begin{array}{l}\text { 1. Satisfaction upon the service } \\
\text { given by the employee. }\end{array}$ \\
\hline & & & $\begin{array}{l}\text { 2. Comfortable upon the service } \\
\text { given. }\end{array}$ \\
\hline & & & 3. Expectation compliance \\
\hline & & & 4. Willingness to stay \\
\hline & & & $\begin{array}{l}\text { 5. Eager to recommend it to other } \\
\text { person. }\end{array}$ \\
\hline
\end{tabular}

\section{Result of The Research}

\section{Characteristic of Customers}

Based on the data obtained describing that majority customers are females at the age of about 26-34 years and they are business people who are having their income about Rp. 5,000,000 - Rp.10,000,000.- per month and their frequency of staying at the hotel is about 2-3 times. 


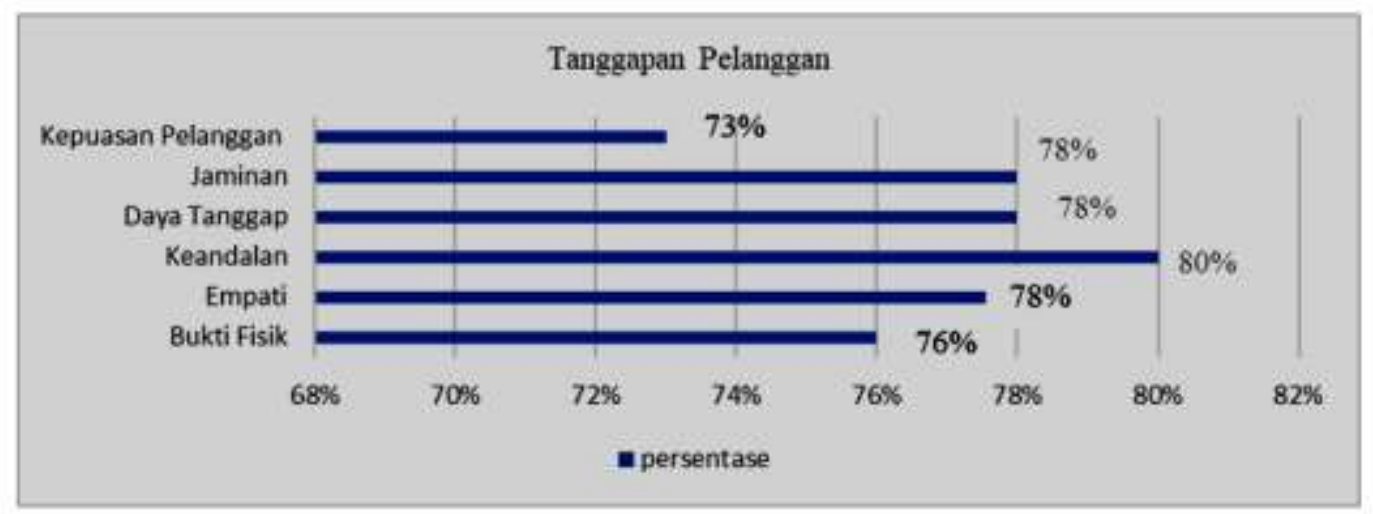

Drawing. Customer feed back about Service Quality and Customer Satisfaction Source : Data processed, 2018

Drawing 3 indicated feed-back from customers against physical evidence of $76 \%$ describing that physical evidence at Royal Safari Garden Resort and Convention Cisarua Bogor is within good category. Customer feed-back about empathy indicated $78 \%$ which was in satisfied category. Customer feed-back about reliability indicated $80 \%$ which was within satisfied category. Customer feed-back about responsiveness indicated $79 \%$ which was within category satisfied. Customer feed-back about assurance indicated $78 \%$ which was within category satisfied. Customer feed-back about customer satisfaction was $73 \%$ which is within category satisfied.

\section{Instrument Validity and Reliability Test}

Validity test is to measure the questions in the questionnaire. Valid means that the instrument being used can measure the item which is going to be measured (Sugiyono, 2013:348). An indicator mentioned on the questionnaire is valid when it has correlation coefficient of product moment of equal or same with $0.30(\geq 0.30)$ which is a reference value to make a decision on this validity test (Sugiyono, 2013:174). Reliability test is to depict an exact value of questionnaire, it means that if research technics is evaluated within the same group but in a different time, nevertheless the result will be the same. According to Sugiyono (2013:134) criteria of a research instrument is reliable when $r$ count $\geq 0.6$. Based on the test of the instrument given to thirty (30) customers has shown that validity test of independent variables of physical evidence, empathy, reliability, responsiveness and assurance as well as independent factor of customer satisfaction are valid. Furthermore, they can go through reliability test.

\section{Classic Assumption Test}

Result of classic assumption test that is consisting of 1) normality test indicates that the data is normal distributed: 2) Multicolinearity test indicates that there is not any multicolony among independent variables; 3 ) Heteroscedasticity test indicates there is not any heteroscedasticity of all regression model, therefore, all regression model can go through multiple linear regression test. 


\section{Result of Data Processing}

Data analysis using SPSS type 20.0 and the result is as the following:

Table. Summary of the calculation of Service Quality upon Customers Satisfaction

\begin{tabular}{|c|c|c|c|c|c|}
\hline \multirow{2}{*}{ Model } & \multicolumn{2}{|c|}{ Unstandardized Coefficients } & \multirow{2}{*}{$\begin{array}{c}\begin{array}{c}\text { Standardized } \\
\text { Coefficients }\end{array} \\
\text { Beta }\end{array}$} & \multirow{2}{*}{$t$} & \multirow{2}{*}{ Sig. } \\
\hline & B & Std. Error & & & \\
\hline (Constant) & 11.383 & 1.791 & & 6.357 & .000 \\
\hline $\begin{array}{l}\text { Physic } \\
\text { evidence/tangible }\end{array}$ & .023 & .086 & .024 & 2.271 & .017 \\
\hline Empathy & .327 & .106 & .434 & 3.071 & .003 \\
\hline $\begin{array}{l}\text { Kehandalan } \\
\text { Reliability }\end{array}$ & .220 & .083 & .297 & 2.660 & .009 \\
\hline Responsiveness & .210 & .103 & .277 & 2.040 & .044 \\
\hline Assurance & .045 & .092 & .057 & 2.085 & .029 \\
\hline t-tabel & \multicolumn{5}{|l|}{$=1.661$} \\
\hline F-count & \multicolumn{5}{|l|}{$=2.31$} \\
\hline Sig & \multicolumn{5}{|l|}{$=.000$} \\
\hline F Tabel & \multicolumn{5}{|l|}{$=6.483$} \\
\hline $\mathrm{R}$ & \multicolumn{5}{|l|}{$=.873$} \\
\hline $\mathrm{R}^{2}$ & \multicolumn{5}{|l|}{$=.762$} \\
\hline Adjusted $\mathrm{R}^{2}$ & \multicolumn{5}{|l|}{$=.750$} \\
\hline Alpha (a) & \multicolumn{5}{|l|}{$=5 \%$} \\
\hline
\end{tabular}

Source: Data processed, 2018

Based on the summary of the calculation result using multiple linear regression has indicated $R$ of 0.873 explaining that the correlation between service quality variable and customer satisfaction variable is strong. 95\% of service quality variable either simultaneously or partially has affected customer satisfaction. However, $\mathrm{R}^{2}$ value has indicated $76.2 \%$ of dependent variable, but the remaining of $23.8 \%$ has been affected by product quality, price, emotional factor, cost and ease (Irawan, 2004:37)

\section{Description}

\section{The Effect of Service Quality upon Customer Satisfaction}

In order to prove that the effect of service quality simultaneously (physical evidence, empathy, reliability, responsiveness, assurance) upon customer satisfaction has applied F-test statistics. . Result of analysis has obtained $F_{\text {count }}$ of 6.483 and $T_{\text {table }}$ for $\alpha=0.05$ which is 2.31 describing that $F_{\text {count }}>F_{\text {table }}(6.483>2.31)$ indicating that $\mathrm{Ho}$ is rejected but $\mathrm{Ha}$ is accepted explaining that trustworthy level of $95 \%$, it has depicted positive and significant impact simultaneously upon customer service. This result is in compliance with the research done by Rahayu (2015) describing that service quality has affected positively and significantly customer satisfaction. Nilasari and Istiatin (2015) concluded that physical evidence, empathy, reliability, responsiveness, assurance have affected positively and significantly the customer satisfaction.

\section{The Effect of Physic Evidence upon Customer Satisfaction}

Result of $T_{\text {count }}$ of physic evidence variable of 2.271 and table for $\alpha=0.05$ is 1.661 describing that $t_{\text {count }}>t_{\text {table }}(2.271>1.661)$. Ho is rejected and $\mathrm{Ha}$ is accepted explaining that physic evidence has positively and significantly affect customer satisfaction. This result is in compliance with Khusaini (2016) and Rachman (2014) description who said that physic evidence had positively and significantly affected customer satisfaction. 


\section{The Effect of Empathy upon Customer Satisfaction}

$T_{\text {count }}$ of empathy variable of 3.071 and table for $\alpha=0.05$ is 1.661 has explained that $t_{\text {count }}>t_{\text {table }}(3.071>1.661)$. Ho is rejected and $\mathrm{Ha}$ is accepted, it means that empathy has positively and significantly affected customer satisfaction. It is in compliance with Ilham(2017) and Akbar(2016) who described that empathy had positively and significantly affected customer satisfaction.

\section{The Effect of Reliability upon Customer Satisfaction}

$T_{\text {count }}$ of Reliability variable of 2.660 and table at $\alpha=0.05$ is 1.661 explaining that $t_{\text {count }}$ $>$ table $(2.660>1.661)$. Ho is rejected but $\mathrm{Ha}$ is accepted describing that reliability variable has positively an significantly affected customer satisfaction. This result is in accordance with Apriyani (2017) and Najmin (2017) who described that reliability had positively and significantly influenced customer satisfaction.

\section{The Effect of Responsiveness upon Customer Satisfaction}

$T_{\text {count }}$ of responsiveness variable of 2.040 and table at $\alpha=-0.05$ is 1.661 describing that tcount $>$ ttable $(2.040>1.661)$. Ho is rejected but $\mathrm{Ha}$ is accepted describing that responsiveness has positively and significantly affected customer satisfaction. This result is getting along with Astuti (2017) and Koestanto (2015) who described that responsiveness had positively affected customer satisfaction.

\section{The Effect of Assurance upon Customer Satisfaction}

$T_{\text {count }}$ of assurance variable of 2.085 and table at $\alpha=0.05$ is 1.661 describing that $t_{\text {count }}>$ table $(2.085>1.661)$. Ho is rejected but $\mathrm{Ha}$ is accepted explaining that assurance has positively and significantly affected customer satisfaction. This result is in compliance with Apriyani (2017) and Sudirjo (2015) who described that assurance had positively and significantly affected customer satisfaction. According to the customers evaluation about the effect of service quality (physic evidence, empathy, reliability, responsiveness and assurance) upon customer satisfaction at Royal Safari Garden Resort and Convention Cisarua Bogor, the following recapitulation has been describing it partially:

Table. Recapitulation of the test upon regression coefficient partially.

\begin{tabular}{|c|l|c|c|c|}
\hline No & $\begin{array}{l}\text { Service Quality upon Customer } \\
\text { Satisfaction }\end{array}$ & $\mathbf{t}$ tabel & $\mathbf{t}$ count & Description \\
\hline 1 & Physic evidence & 1,661 & 2,271 & Positive and significant effect \\
\hline 2 & Empathy & 1,661 & 3,071 & Positive and significant effect \\
\hline 3 & Reliability & 1,661 & 2,660 & Positive and significant effect \\
\hline 4 & Responsiveness & 1,661 & 2,040 & Positive and significant effect \\
\hline 5 & Assurance & 1,661 & 2,085 & Positive and significant effect \\
\hline
\end{tabular}

Source : Data processed, 2018

Based on the table above, it is indicating that service quality variables (Physic evidence, empathy, reliability, responsiveness and assurance), each one of them has affected customer satisfaction. And the biggest variable which has influenced employees performance is empathy because they have been providing best service to the customers. Lupiyoadi (2014:217) described that empathy of the service corporation has figured out an individual honest attitude provided by the organization to the customers thru special care and honest attitude to the customers which will impact to the customers satisfaction, since they have been treated very well. 


\section{Conclusion and Suggestions}

Referring to the result and description of the research, it has come to the conclusion as follows:

1. In accordane with the customers feed-back about service quality and customer satisfaction: a)Physic evidence is good: b) Empathy at the hotel is good: c) Reliability of the hotel is good: d) Responsiveness is good: e) Assurance is good: f) Customer satisfaction is good.

2. Service quality simultaneously has positively and significantly affected customer satisfaction.

3. Partial tests of physic evidence, empathy, reliability, responsiveness and assurance have positively and significantly affected customer satisfaction.

The following suggestions are offered:

1. Based on the customers feed-back about service quality and customer satisfaction, some suggestions are offered to Royal Safari Garden Resort and Convention Cisarua Bogor: a) it is necessary to improve rooms cleanliness, area surrounding the hotel and project of construction in front of the hotel have to be completed as soon as possible to give a comfortable place for the customers or visitors; b) to improve customer service 24 hours open; c) it is necessary to follow the procedure of registration c/in and c/out to avoid any complexity and to make customers waiting ; d) to improve the service to be more responsive handling the complaints; e) to improve customers security refers to the data of the guests who decide to stay overnight, staying and leaving the hotel : f) to improve service quality meeting the customers expectation, so that they will recommend the hotel to other person.

2. It is important to be concerned about employees response to handle customers complaints in order to evolve service quality provided to the customers and made them satisfied.

\section{Acknowledgement}

Thanks to Royal Safari Garden and Convention Cisarua Bogor that had given me the opportunity to do a reseach and to all the custmers, guests, visitors who had been participating to complete the questionnaires offered.

\section{References}

Agustini, Titin, Titiek Tjahja Andari dan Rahmat Gunawan. 2015. Pengaruh Kualitas Jasa terhadap Kepuasan Pasien Jamkesda Rawat Inap di RSP Dr. M. Goenawan Partowidigdo Cisarua Bogor. Jurnal Visionida Universitas Djuanda Bogor. Vol. 1 No. 1, Juni 2016. Hal 17-20.

Akbar, Robby Nur dan Zainul Arifin. 2016. Pengaruh Kualitas Pelayanan terhadap Kepuasan Pelanggan (Studi pada Nsabah Prioritas PT AIA Financial Cabang Malang, Jawa Timur) Jurnal Manajemen dan Bisnis. Vol.30 No.1, Januari 2016. Hal 1-8.

Alma, Buchari. 2011. Manajemen Pemasaran dan Pemasaran Jasa. Bandung. Alfabeta.

Apriyani, Dwi Aliyyah dan Sunarti. 2017. Pengaruh Kualitas Pelayanan terhadap Kepuasan Konsumen (Survei pada Konsumen The Little A Coffee Shop Sidoarjo). Jurnal Manajemen dan Bisnis. Vol. 51 No.2, Oktober 2017. Hal 1-7. 
Arikunto, Suharsimi. 2013. Prosedur Penelitian: Suatu Pendekatan Praktik. Cetakan ke15. Jakarta. Rineka Cipta.

Astuti, Leni. 2017. Pengaruh Kualitas Pelayanan dan Kepuasan Konsumen terhadap Loyalitas Pelanggan (Studi pada Bank Jateng Syariah Universitas Muhammadiyah Surakarta), Jurnal Studi Manajemen. Vol.4 No.1, 2017. Hal 171-180.

Badan Pusat Statistik Nasional. 2018. Perkembangan Pariwisata dan Transportasi Nasional 2017, Badan Pusat Statistik. No. 13/02/Th.XXI, 1 Feberuari 2018.

Badan Pusat Statistik Nasional. 2018, Pertumbuhan Ekonomi Indonesia Triwulan IV2017, Badan Pusat Statistik. No. 16/02/Th.XXI, 5 Februari 2018.

Badan Pusat Statistik. 2017. Kabupaten Bogor dalam Angka 2017, Bogor: Badan Pusat Statistik. ISSN : 0215-4250.

Baharudin. 2012. Analisis Pengaruh Keandalan, Jaminan dan Daya Tanggap Terhadap Kepuasan Pelanggan dalam Menggunakan Jasa PT. Apex Semarang, Jurnal Manajemen. Univeristas Diponegoro. Vol. 5 No.7, 2017. Hal 5-50.

Dewi, Meutia. 2016. Pengaruh Kualitas Pelayanan Terhadap Kepuasan Pasien Pengguna BPJS pada Rumah Sakit Rehabilitasi Medik kabupaten Aceh Timur, Jurnal Manajemen dan Keuangan Universitas Samudra. ISSN : 2252-B44X. Vol. 5 No. 2, November 2015. Hal 535-544.

Handayani, Aries Wiwit. 2006. Analisis Kepuasan Pelanggan untuk Meningkatkan Kualitas Pelayanan Admisi dan Promosi Universitas Bakrie, Jurnal OE. Vol. 7 No. 1, Maret 2015. Hal 15-32.

Hardiyati, Ratih. 2010. Analisis Pengaruh Kualitas Pelayanan Terhadap Kepuasan Konsumen Menggunakan Jasa Penginapan (Villa) Agrowisata Kebun Teh Pagilaran, Jurnal Ekonomi. Vol. 3 No. 1, 2010. Hal 110-132.

Ilham, Muhammad. 2017. Pengaruh Experinetal Marketing dan kualitas Layanan Terhadap Kepuasan Pelanggan dan Dampaknya Terhadap Loyalitas Pelanggan pada Hotel Dirgantara Semarang, Jurnal Studi Manajemen. Vol. 4 No.6, 2017. Hal 1-31.

Irawan, Handi. 2009. 10 Prinsip Kepuasan Pelanggan. Cetakan ke-7. Jakarta. Bumi Aksara.

Koestanto, Tri Hary. 2014. Pengaruh Kualitas Pelayanan terhadap Kepuasan Pelanggan pada PT Bank Jatim Cabang Klampis Surabaya. Jurnal Studi Manajemen. Vol.3 No.2, 2014. Hal 201-214.

Khusaini, Ahmad. 2016. Analisis Kualitas Pelayanan terhadap Kepuasan Konsumen di Spa Club Arena Yogyakarta, Jurnal Manajemen Universitas Udayana Bali. ISSN : 2085-0972. Vol. 3 No. 2, 2016. Hal 55-58.

Maulana, Putra Akbar. 2010. Peranan Front Office Departement di Hotel Danau Toba Internasional. Jurnal. Program Studi Diploma III Pariwisata Bidang Keahlian Perhotelan, Fakultas Sastra, Universitas Sumatra Utara. Vol. 3 No. 5, 2010. Hal 1-10. 
Merdian, Wili Andri. 2007. Analisis Pengaruh Kualitas Pelayanan terhadap Kepuasan Pelanggan (Studi Kasus Tiki Yogyakarta), Jurnal Manajemen Universitas Sanata Dharma Yogyakarta. ISSN : 1410 - 9913. Vol. 3 No. 1, 2007.Hal 66-67.

Najmi, Fahlin. 2017. Pengaruh Keandalan dan Prosedur Pelayanan Terhadap Kepuasan Masyarakat pada Kantor Urusan Agama Liang Anggang Kota Banjarbaru, Jurnal Manajemen Universitas Islam Batik Surakarta. ISSN : 1693-0827. Vol. 13 No. 1, 2015. Hal 11-12.

Nilasari, Eswika dan Istiatin. 2015. Pengaruh Kualitas Pelayanan Terhadap Kepuasan Konsumen pada Dealer PT. Ramayana Motor Sukoharjo. Jurnal IImiah Ekonomi Bisnis. ISSN : 2442-4560. Hal 251-263.

Normasari, Selvy, Srikandi Kumadji dan Andriani Kusumawati. 2013. Pengaruh Kualitas Pelayanan Terhadap Kepuasan Pelanggan, Citra Perusahaan dan Loyalitas Pelanggan (Survei pada Tamu Pelanggan yang Menginap di Hotel Pelangi Malang). Jurnal Administrasi Bisnis. ISSN : 2302-8912. Vol. 6 No. 2 Desember 2013. Hal 3-5.

Panjaitan, Januar Efendi dan Ai Lili Yulianti. 2016. Pengaruh Kualitas Pelayanan terhadap Kepuasan Pelanggan pada JNE Cabang Bandung, Jurnal Manajemen Universitas Telkom. ISSN : 2252- 8520. Vol. 11 No. 2, September 2016. Hal 256.

Rachman, Eriek Syarief. 2013. Pengaruh Kualitas Pelayanan Terhadap Kepuasan Pelanggan pada Travel Cipaganti Group di Jember. Jurnal Pendidikan Ekonomi Universitas Jember. Vol. 6 No. 4, 2013. Hal 12-24.

Rahardjo, Ricky. 2016. Analisa Pengaruh Kualitas Pelayanan terhadap Kepuasan Pelanggan Premiere Auto Derailing Semarang. Jurnal Studi Ekonomika dan Bisnis Universitas Diponegoro Semarang. Vol.2 No.2, 2016. Hal 16-20.

Raharjani, Jeni. 2005. Analisa Faktor-Faktor yang Mempengaruhi Keputusan Pemilihan Pasar Swalayan sebagai Tempat Berbelanja (Studi Kasus pada Pasar Swalayan di Kawasan Seputar Simpang Lima Semarang). Jurnal Studi Manajemen dan Organisasi. Vol.2 No.1, Januari 2005. Hal 11-24.

Rahayu, Irah. 2015. Pengaruh Kualitas Pelayanan terhadap Kepuasan Konsumen pada Hotel Kumala di Samarinda, Jurnal Administrasi Bisnis Universitas Mulawarman. ISSN : 2355-5408. Vol. 3 No. 1, 2015: 55-56. Hal 55-59.

Sugiyono. 2013a. Metode Penelitian Kuantitatif, Kualitatif dan Kombinasi (Mixed Methods). Cetakan Ketiga. Jakarta. Alfabeta.

. 2013 . Metode Penelitian Kuantitatif, Kualitatif dan R\&D. : Jakarta. Alfabeta.

Suryadharma, I Wayan Widya dan I Ketut Nurcahya, 2015, Pengaruh Kualitas Pelayanan pada Kepuasan Pelanggan Hotel Bintang Pesona di Denpasar Timur. Jurnal Manajemen Universitas Udayana Bali. ISSN : 2302-8912. Vol. 4 No. 4, 2015: 930-942. Hal $930-932$.

Susepti, Amalia, Djamhur Hamid dan Andriani Kusumawati. 2017. Pengaruh Kualitas Pelayanan Terhadap Kepuasan dan Loyalitas Tamu Hotel (Studi tentang Persepsi Tamu Hotel MAHKOTA Plengkung Kabupaten Banyuwangi), Jurnal Administrasi Bisnis Universitas Brawijaya Malang. ISSN : 1540-7144. Vol. 50 No. 5, September 2017. Hal $27-35$.

Tjiptono, Fandy. 2014. Pemasaran Jasa. Yogyakarta. Andi. 
The Management Journal of BINANIAGA Vol. 04, No. 02, December 2019

p-ISSN: 2527 - 4317, e-ISSN: $2580-149 x$

$6^{\text {th }}$ Accreditation Rating: April 04, 2019-April 03, 2024

Umar, Husein. 2008. Metode Penelitian untuk Skripsi dan Tesis Bisnis. Jakarta. PT. Raja Grafindo Persada.

Dwi Gemina and Rully Zulkiply. The Effect of Quality of The Service Upon Customer Satisfaction at Royal Safari Garden Resort and Convention Cisarua Bogor 